\title{
Ekstrak ikan haruan (Channa striata) meningkatkan jumlah neokapiler pada penyembuhan luka (Extract of haruan (Channa striata) increases neocapillaries count in wound healing process)
}

\author{
${ }^{1}$ Muhammad Reza Setiawan, ${ }^{2}$ Nurdiana Dewi, ${ }^{3}$ Ika Kustiyah Oktaviyanti \\ ${ }^{1}$ Mahasiswa Program Studi Kedokteran Gigi \\ ${ }^{2}$ Bagian Biologi Oral, Program Studi Kedokteran Gigi \\ ${ }^{3}$ Bagian Patalogi Anatomi, Fakultas Kedokteran \\ Universitas Lambung Mangkurat \\ Banjarmasin, Indonesia
}

\begin{abstract}
Haruan is Kalimantan's indigenous fish which has the potency to accelerate wound healing. Haruan extract has substantial properties such as albumin, $\mathrm{Zn}, \mathrm{Cu}$, and Fe to accelerate wound healing. The purpose of this study is to assess the effect of haruan extract on wistar rats buccal mucosa wound healing on day 1, 3, 5, and 7 histopathologically. This study was purely experimental with pretest-posttest with control group design. Samples were divided into 4 treatment groups, haruan extract 25\%, 50\%, 100\% treatment groups and aquadest treatment group as negative control, each treatment was performed for 7 days. Neocapillaries count reached its peak on day 5. Mean neocapillaries scoring of each group was 12, 16.5, 18.5, 6 respectively. Two way Anova and post hoc LSD tests presented a significant difference between negative control and haruan extract groups. In conclusion, haruan extract treatment significantly increased neocapillaries count in wound healing process.
\end{abstract}

Keywords: haruan extract, wound healing, neocapillaries, histopathology

\begin{abstract}
ABSTRAK
Haruan adalah ikan khas Kalimantan yang berpotensi mempercepat penyembuhan luka. Ekstrak ikan haruan mengandung zat penting seperti albumin, $\mathrm{Zn}, \mathrm{Cu}$, dan Fe untuk mempercepat penyembuhan luka. Penelitian ini dimaksudkan untuk mengetahui pengaruh ekstrak ikan haruan pada proses penyembuhan luka pada mukosa bukal tikus wistar hari ke-1, 3, 5, dan 7 secara histopatologi. Penelitian eksperimental murni dengan pretest-posttest with control group ini, meliputi 4 kelompok, yaitu kelompok hewan yang diberi ekstrak haruan selama 7 hari dengan konsentrasi berturut-turut 25\%, 50\%, $100 \%$, dan kelompok kontrol negatif diberi akuades. Hasilnya menunjukkan bahwa jumlah neokapiler mencapai puncak pada hari ke-5. Rerata jumlah neokapiler pada tiap kelompok berturut adalah 12; 16,5; 18,5; dan 6. Uji Anova 2-jalur dan uji post hoc LSD menunjukkan adanya perbedaan bermakna antara kontrol negatif dan ekstrak ikan haruan. Berdasarkan hasil penelitian, disimpulkan bahwa pemberian ekstrak ikan haruan secara bermakna meningkatkan jumlah neokapiler pada proses penyembuhan luka.
\end{abstract}

Kata kunci: ekstrak ikan haruan, penyembuhan luka, neokapiler, histopatologi

Koresponden: Muhammad Reza Setiawan, Program Studi Kedokteran Gigi Fakultas Kedokteran Universitas Lambung Mangkurat, Jl. Veteran 128B Banjarmasin, Kalimantan Selatan, E-mail: rezaasetiawan@gmail.com

\section{PENDAHULUAN}

Pada dasawarsa terakhir ini, obat tradisional semakin populer. Bahan obat-obatan tradisonal bisa terbuat dari binatang atau tumbuhan, yang banyak digunakan sebagai obat alternatif untuk memenuhi kebutuhan dasar masyarakat di bidang kesehatan. Keuntungan menggunakan obat tradisional, yaitu murah, mudah didapat dan efek sampingnya minimal dibandingkan obat kimia. ${ }^{1,2}$ Salah satu bahan obat tradisional yang berpotensial digunakan adalah ikan haruan. ${ }^{2}$ Indonesia, secara khusus di Kalimantan, merupakan habitat asli ikan haruan. Selain terkenal dengan rasanya yang khas, masyarakat Kalimantan Selatan sering mengkonsumsi ikan haruan untuk membantu mempercepat penyembuhan luka. ${ }^{3-5}$

Hasil penelitian Restiana $e t a l^{4}$ dan Soemaridini et $a l^{3}$ menunjukkan ikan haruan merupakan salah satu jenis ikan yang memiliki kandungan albumin cukup tinggi. Albumin sangat diperlukan tubuh manusia setiap hari, terutama dalam proses penyembuhan luka. Penelitian lain tentang kandungan ekstrak haruan oleh Santoso et $a l^{5}$ menyatakan bahwa ekstrak ikan haruan juga mengandung senyawa-senyawa penting bagi tubuh manusia diantaranya Zinc (Zn), tembaga $(\mathrm{Cu})$, dan besi $(\mathrm{Fe})$ yang peranannya meningkatkan kekebalan tubuh. Tembaga dapat meningkatakan vascular endhotelial growth factor(VEGF) sehingga angiogenesis meningkat.

Rongga mulut sebagai bagian integral tubuh sering mengalamitrauma saat melakukan fungsinya. Trauma ini dapat terjadi secara disengaja maupun tidak yang pada akhirnya akan menimbulkan luka pada mukosa mulut. Luka merupakan perubahan kontinuitasjaringan secara sel dan anatomi yang dapat 
terjadi pada kulit ataupun mukosa dan berespon pada proses penyembuhan luka. Penyembuhan luka terjadi untuk memperbaiki kerusakan jaringan tubuh. Fasefase yang terjadi saat penyembuhan luka adalah inflamasi, proliferasi, dan remodeling. ${ }^{6,7}$ Inflamasi terjadi dalam beberapa menit setelah luka dan disertai dengan terjadinya tanda inflamasi lokal. Proliferasi terjadi pada akhir fase inflamasi dan di dalamnya terjadi proliferasi fibroblas, kolagen, dan neokapiler. Setelah itu terjadi fase remodeling yang merupakan tahap akhir dalam proses penyembuhan luka yang berlangsung dalam 3 minggu sampaiberbulan-bulan untuk menormalkan semua yang abnormal.,

Neokapiler memiliki peran yang penting pada fase proliferasi, karena neokapiler adalah pembuluh darah baru berupa tunas-tunas yang terbentuk dari pembuluh darah yang telah ada sebelumnya dan akan berkembang menjadi percabangan baru dari jaringan luka. Hal ini merupakan proses alami yang penting dan diperlukan pada penyembuhan luka untuk mengembalikan aliran darah pada jaringan setelah terjadi luka, sehingga jaringan-jaringan yang baru mendapatkan asupan nutrisi yang adekuat untuk berproliferasi. Pembentukan pembuluh darah baru terjadi pada hari ke-2 sampai minggu ke-3 setelah terjadinya luka, yang puncaknya terjadi pada hari ke5. Adanya peningkatanjumlah pembuluh darah baru berarti proses penyembuhan luka berjalan..$^{10,11}$

Penelitian ini dimaksudkan untuk mengetahui pengaruh ekstrak ikan haruan terhadap jumlah neokapiler pada proses penyembuhan luka mukosa bukal tikus wistar.

\section{BAHAN DAN METODE}

Penelitian inibersifat eksperimen murni dengan rancangan pretest-posttest only with control group dengan rancangan acak lengkap, dinyatakan laik etik oleh Komisi Etik Penelitian Kesehatan Universitas Lambung Mangkurat melalui surat keterangan No. 060/KEPK-FK UNLAM/EC/VI/2014.

Penelitian diawali dengan memilih ikan haruan hidup untuk menjaga kualitas ekstrak yang akan dihasilkan. Selanjutnya, ikan haruan dibersihkan dari sisik dan isi perut dibuang lalu dagingnya dipotong dalamukuran yang kecil dengan potongan melintang dengan membuang tulangnya. Pembuatan ekstrak daging ikan haruan dilakukan di Laboratorium Kimia Fakultas MIPA UNLAMBanjarbaru. Ekstrak haruan diolah dengan cara dikukus dengan perbandingan akuades dan ikan haruan 1:1. Akuades dimasukkan terlebih dahulu ke dalam panci kukus kemudian ditutup dengan saringan, dan ikan haruan diletakkan di atas saringan, dikukus dengan suhu $70^{\circ} \mathrm{C}$ dengan api sedang selama 50 menit sehingga diperoleh cairan kuning. Cairan tersebut kemudian dirotari selama 5 jamuntuk memisahkan akuades dan ekstrak sehingga dihasilkan cairan yang pekat berupa cairan berwarna kuning muda pekat kemudian disaring agar bersih dari kotoran, lalu disimpan dalam wadah. Pembuatan ekstrak konsentrasi $25 \%$ dengan cara mencampur 10 mL ekstrak ikan haruan $100 \%$ dengan $30 \mathrm{~mL}$ akuades (perbandingan 1:3), konsentrasi 50\% dengan cara mencampur $20 \mathrm{~mL}$ ekstrak ikan haruan $100 \%$ dengan $20 \mathrm{~mL}$ akuades (perbandingan 1:1), dan ekstrak ikan haruan $100 \%$ adalah ekstrak yang tidak dicampur apaapa.

Tiga puluh empat tikus wistar jantan, berat 200250 g, umur 2-2,5 bulan, pergerakan aktif dalam kondisi sehat dibagi menjadi tujuh belas kelompok tikus yang terdiri dari 4 perlakuan, yaitu akuades, ekstrak haruan $25 \%$, ekstrak haruan $50 \%$, dan ekstrak haruan $100 \%$. Perlakuan pada hewan dan pembuatan preparat histologis dikerjakan di Balai Veteriner Banjarbaru. Setelah anastesi inhalasi, dibuat luka sayat sepanjang $1 \mathrm{~cm}$ dan sedalam $1 \mathrm{~mm}$ dengan menggunakan scalpel dan blade steril. Pemberian obat dilakukan secara intra oral menggunakan sonde lambung setiap 24 jam sekali. Dosis ekstrak haruan adalah $10 \mathrm{~mL} / \mathrm{g} \mathrm{BB}$, kemudian dilakukan dekapitasi pada hari ke-1, 3, 5, dan 7 .

Jaringan mukosa bukal diambil dan difiksasi dengan buffer neutral formalin (BNF) 10\% selama 24 jam, kemudian dilakukan processing jaringan dan penanaman pada blok parafin. Blok parafin lalu dipotong dengan ketebalan $5 \mu \mathrm{m}$ dan diletakkan pada gelas objek, dideparafinisasi dan didehidrasi pada jaringan yang berada pada gelas objek, selanjutnya dilakukan pewarnaan hematoksilin eosin (HE).

Neokapiler diamati menggunakan mikroskop cahaya yang dilengkapi kamera digital pembesaran 100x. Hasil penelitian diuji normalitasnya dengan Shapiro Wilk dan dianalisis dengan menggunakan uji Anova 2-jalur kemudian dilanjutkan dengan uji post hoc LSD.

\section{HASIL}

Rata-rata jumlah neokapiler pada kelompok akuades serta ekstrak haruan $25 \%, 50 \%$, dan $100 \%$, dapat dilihat pada Gambar 1. Secara umum jumlah neokapiler pada kelompok perlakuan lebih tinggi daripada kelompok kontrol. Kelompok ekstrak ikan haruan konsentrasi 100\% memiliki jumlah rata-rata tertinggi. Jumlah rata-rata neokapiler meningkat pada pengamatan hari ke-1 di setiap kelompok perlakuan maupun kelompok kontrol negatif. Jumlah rata-rata neokapiler tertinggi terdapat pada pengamatan hari ke-5. Jumlah rata-rata neokapiler menurun pada hari ke-7 di setiap kelompokperlakuan dan kontrol negatif. 


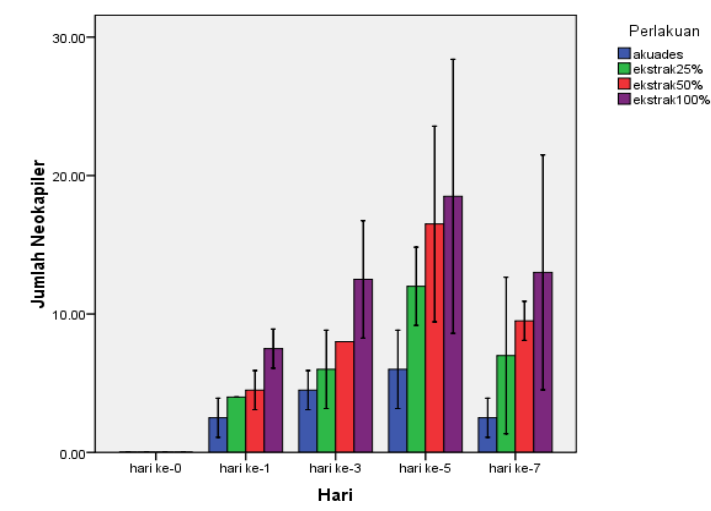

Gambar 1 Grafik rata-ratajumlah neokapiler kelompok perlakuan (ekstrak ikan haruan 25\%, 50\%, dan 100\%), dan kontrol negatif (akuades) pada hari ke-0 hingga hari ke-7.

Setelah tabulasi data, dilakukan uji normalitas Shapiro-Wilk denganjumlah sampel yang digunakan kurang dari 50, yaitu dari uji normalitas neokapiler pada kelompok hari (hari 1, 3, 5, dan 7) didapatkan data terdistribusi normal berturut-turut dengan nilai $\mathrm{p}=0,450,0,393,0,943$, dan 0,499; sedangkan pada kelompok perlakuan (akuades, ekstrak haruan $25 \%$, $50 \%$, dan $100 \%$ ) didapatkan data terdistribusi normal berturut-turut dengan nilai $\mathrm{p}=0,732,0,623,0,681$, dan 0,745 . Selanjutnya dilakukan uji homogenitas varians Levene's yang mendapat bahwa kelompok hari memiliki nilai signifikansi 0,153 dan kelompok perlakuan memiliki nilai signifikansi 0,080 . Hasil tersebut menunjukan bahwa data hasil penghitungan jumlah neokapiler memiliki varian yang homogen.

Dengan uji parametrik Anova 2-jalur, diketahui bahwa uji beda jumlah neokapiler berdasarkan hari maupun perlakuan memiliki nilai signifikansi 0,000 yang berarti terdapat perbedaan bermakna jumlah neokapiler pada kelompok hari maupun perlakuan. Hasil intrepretasi interaksi dua faktor, yaitu perlakuan dan hari pengamatan didapatkan nilai signifikansi 0,025 yang berarti terdapat interaksi antara macam perlakuan dengan hari dilakukan pengamatan yang menyebabkan jumlah neokapiler berbeda secara signifikan pada taraf kepercayaan $95 \%$. Uji post hoc LSD pada kelompok hari memberikan hasil bahwa tingkat signifikansi yang tertinggi terdapat pada hari ke-5 dengan nilai signifikansi 0,000 , dengan rerata hitung tertinggi yaitu 13,25 . Sementara uji post hoc LSD pada kelompok perlakuan memberi hasil bahwa ada perbedaan bermakna antara kelompok ekstrak ikan haruan $25 \%$ dan akuades dengan nilai signifikansi 0,006, kelompok ekstrak ikan haruan $50 \%$ dan akuades nilai signifikansi 0,000 , kelompok ekstrak haruan $100 \%$ dan akuades nilai signifikansi 0,000 . Tingkat signifikansi antara kelompok ekstrak ikan haruan 25\% dan ekstrak ikan haruan 50\% sebesar
0,042 yang menunjukkan ada perbedaan bermakna antara kelompok perlakuan ekstrak ikan haruan $25 \%$ dan ekstrak ikan haruan 50\%. Tingkat signifikansi antara ekstrak ikan haruan $100 \%$ dan ekstrak ikan haruan $25 \%$ sebesar 0,000 yang menunjukkan adanya perbedaan yang bermakna antara kelompok perlakuan ekstrak ikan haruan konsentrasi $25 \%$ dan $100 \%$. Tingkat signifikansi antara ekstrak ikan haruan 100\% dan ekstrak ikan haruan 50\% sebesar 0,008 yang menunjukkan adanya perbedaan bermakna antara kelompok perlakuan ekstrak 100\% dan ekstrak ikan haruan $50 \%$.

Uji post hoc LSD pada hari ke-1 menunjukkan bahwa ada perbedaan bermakna antara kelompok akuades dan ektrak ikan haruan 100\% dengan nilai signifikan 0,001, kelompok perlakuan ekstrak ikan haruan $25 \%$ dan $100 \%$ dengan nilai signifikan 0,005 , ekstrak ikan haruan 50\% dan kelompok akuades dengan nilai signifikan 0,031, kelompok ekstrak ikan haruan $100 \%$ dan kelompok ikan haruan 50\% dengan nilai signifikan 0,008. Hari ke-3 menunjukkan hasil bahwa terdapat perbedaan bermakna antara kelompok akuades dan ekstrak ikan haruan $100 \%$ dengan nilai signifikansi 0,004 , ekstrak ikan haruan 25\% dan ekstrak ikan 100\% dengan nilai signifikansi 0,004, ekstrak ikan haruan 50\% dan ekstrak haruan 100\% dengan nilai signifikansi 0,027 . Tampak hari ke-5 menunjukkan bahwa terdapat perbedaan bermakna antara kelompok akuades dan ekstrak ikan haruan $50 \%$ dengan nilai signifikansi 0,031 , akuades dan ekstrak ikan haruan 100\% dengan nilai signifikansi 0,017. Pada hari ke-7 terdapat perbedaan bermakna antara kelompok akuades dan ekstrak ikan haruan $100 \%$ dengan nilai signifikansi 0,016 .

\section{PEMBAHASAN}

Hasilpenelitian menunjukkan bahwa kelompok perlakuan dan kontrol terdapat perbedaan bermakna. Hal ini kemungkinan disebabkan adanya senyawasenyawa pada ekstrak ikan haruan sehingga lebih terpenuhinya nutrisi yang diperlukan dalam masa penyembuhan. Ekstrak ikan haruan mengandung senyawa-senyawa yang penting bagi proses sintesis jaringan dan penyembuhan luka, seperti albumin, mineral $\mathrm{Zn}, \mathrm{Cu}$, dan $\mathrm{Fe}$. Berdasar hasil pemeriksaan uji kandungan ekstrak haruan $100 \%$ yang dilakukan didapatkan kandungan albumin 7,568 mg/L, Zn $6,70 \mathrm{mg} / \mathrm{L}, \mathrm{Fe} 0,72 \mathrm{mg} / \mathrm{L}$ dan $\mathrm{Cu} 0,447 \mathrm{mg} / \mathrm{L}$.

Berdasarkan hasil penelitian Restiana et al, ikan haruan merupakan salah satujenis ikan yang memiliki kandungan albumin yang cukup tinggi. ${ }^{6}$ Albumin merupakan salah satu jenis protein; protein berperan untuk meningkatkan proliferasi fibroblas sehingga meningkatkan sintesis, akumulasi dan remodeling 
kolagen. Jika zinc berperan dalam pertumbuhan dan replikasi sel serta berperan dalam respon imun sel. Mineral tembaga yang terkandung di dalam ekstrak haruan berfungsi meningkatkan vascular endhotelial growth factor (VEGF) sehingga aksi angiogenesis meningkat. $\mathrm{Cu}$ dan $\mathrm{Zn}$ dapat berperan mengikat dan mengoptimalkanfungsi enzim superoksida dismutasi (SOD) sehingga dapat mengurangi inflamasi. Besi berperan dalam pembentukan kolagen, dan dalam pengiriman oksigen serta sintesis kolagen dalam proses penyembuhan luka. ${ }^{12,13}$

Pada penelitian yang dilakukan, pada hari ke-1 telah terjadi peningkatan jumlah neokapiler. Hal ini mungkin disebabkan pada saat jaringan mengalami kerusakan, terjadi pelepasan faktor angiogenesis yang akan mulai berikatan dengan reseptor sel endotel untuk mengakomodasi pembentukan neokapiler.

Sesaat setelah terjadi luka pada mukosa bukal tikus wistar, terjadi proses penyembuhan, diawali dengan terbentuknya bekuan darah pada permukaan luka. Setelahitu, terjadilah reaksi inflamasi pada tepi luka. Pada tahap inflamasi, sel-sel inflamasi khususnya makrofag mulai memasuki bekuan darah dan mulai menghancurkannya. Pasca 2-3 hari terjadinya luka, terbentuk jaringan granulasi yang secara histologis, ditandai dengan proliferasi fibroblas dan kapiler baru yang halus dan berdinding tipis. Selama proses penyembuhan luka, fibroblas akan aktif bergerak dari jaringan sekitar luka ke dalam daerah luka, lalu akan berproliferasi serta mengeluarkan beberapa substansi seperti kolagen, elastin, hyaluronic acid, fibronektin dan proteoglycans yang berperan dalam rekontruksi jaringan baru. ${ }^{14,15}$

Hari ke-3 terus meningkat kemungkinan karena adanya induksi dari faktor angiogenik, seperti basic fibroblast growth factor (b-FGF), transforming growth factor (TGF- $\beta$ ), dan VEGF. Faktor-faktor tersebutyang menyebabkan proliferasi, menginduksi sel endotel untuk sekresi proteinase yang berguna untuk memulai degradasi membran basal, memicu migrasi sel endotel, dan peningkatan proliferasi untuk pembentukan pembuluh darah yang baru. Jumlah neokapiler yang terus meningkat juga diakibatkan karena proses angiogenesis terus berlanjut diikuti dengan terjadinya penggabungan sel endotel lain dengan neokapiler yang telah ada untuk memperkuat neokapiler tersebut. ${ }^{15,16}$

Pembentukan neokapiler paling banyak pada hari ke-5, mungkin disebabkan pada hari ke-5 terdapat peningkatan faktor angiogenik seperti b-FGF, TGF$\beta$, epidermal growth factor (EGF), dan VEGF yang membantu angiogenesis. Ruang bekas insisi terisi, jaringan granulasi telah mulai mengisi ruang insisi, serabut kolagen menjadi berlimpah, sel radang hampir hilang, dan serabut kolagennya mulai menjembatani insisi. ${ }^{10,15,16}$ Tingginya jumlah neokapiler dipengaruhi oleh jumlah makrofag yang mengeluarkan faktor angiogenesis (AGF) yang merangsang pembentukan ujung epitel diakhir pembuluh darah. Makrofag dan AGF bersama-sama mempercepat penyembuhan luka. Makrofag juga menghasilkanfibroblast growth factor (FGF) yang menyebabkan sekresi proteinase oleh sel endotel yang dapat memulai pendegradasian membran basal dan merangsang migrasi sel endotel dan proliferasi untuk pembentukan pembuluh darah baru. $^{10}$

Pada hari ke-7 terjadi penurunan pembentukan neokapiler mungkin karena luka sudah mulai sembuh jadi tubuh mulai menghentikan proses pembentukan neokapiler. Penurunan jumlah neokapiler ini juga disebabkan penurunan faktor VEGF, TGF- $\beta$, dan bFGF antara hari ke-7 sampai 14. Penurunan tersebut menunjukkan bahwa neokapileryang terbentuk pada hari ke-1, 3, dan 5 dianggap cukup untuk melakukan tugas sebagai penyuplai darah yang berisikan nutrisi dan faktor lainnya yang berguna untuk penyembuhan, sehingga luka mulai tertutup. ${ }^{14,15}$

Hasil pengamatan menunjukan bahwa jumlah rata-rata neokapiler pada kelompok perlakuan lebih tinggi dibanding kelompok kontrol negatif. Ekstrak ikan haruan $100 \%$ merupakan konsentrasi tertinggi pengaruhnya terhadap jumlah neokapiler daripada ekstrak ikan haruan 25\% serta 50\%. Ekstrak ikan haruan $100 \%$ memiliki pengaruh yang lebih tinggi kemungkinan karena memiliki zat aktif yang lebih banyak dalam membantu proses penyembuhan luka daripada ekstrak ikan haruan $25 \%$ dan $50 \%$. Akan tetapi, pada kelompok ekstrak ikan haruan $100 \%$, beberapa sampel mengalami diare dan mati, maka diperlukan uji toksisitas dengan dosis yang tepat dalam penggunaannya.

Ekstrak haruan 50\% memilikijumlah neokapiler yang lebih kecil daripada ekstrak ikan haruan 100\%. Hal ini mungkin karena adanya penambahan pelarut akuades pada ekstrak ikan haruan 50\%, tetapi ekstrak ikan haruan 50\% memiliki jumlah neokapiler yang lebih tinggi daripada ekstrak ikan haruan $25 \%$, hal ini mungkin karena ekstrak haruan $25 \%$ memiliki zat aktif lebih sedikit daripada ekstrak ikan haruan $50 \%$ dan ekstrak ikan haruan 100\%. Dari hasil ini, disimpulkan semakin tinggi konsentrasi ekstrak ikan haruan, semakin tinggi pengaruhnya terhadap jumlah neokapiler.

Hasil penelitian juga memperlihatkan bahwa akuades tidak memiliki bahan aktif sehingga proses penyembuhan luka lebih lama serta memiliki jumlah neokapileryang rendah. Hal tersebut sangat mungkin karena masih terdapatnya mikroba dan kerusakan 
jaringan yang harus difagosit oleh sel-sel pada daerah luka masih banyak berbeda dengan bahan aktif yang ada pada ekstrak ikan haruan. ${ }^{10}$

Penelitian sebelumnya oleh Sura membuktikan aplikasi ekstrak ikan haruan 100\% secara oral dapat membantu prosespenyembuhan luka kulit punggung mencit. ${ }^{17}$ Pada penelitian ini pemekatan konsentrasi ekstrak ikan haruan dilakukan setelah pengukusan sehingga konsentrasi kandungan zat aktifnya lebih tinggi; berbeda dengan penelitian sebelumnya masih terdapat lebih banyak zat pelarut. Menurut Jannata dkk semakin tinggi konsentrasi, semakin banyak kandungan zat aktif pada ekstrak. ${ }^{18}$

Disimpulkan bahwa ekstrak ikan haruanmemiliki pengaruh terhadap jumlah neokapiler pada proses penyembuhan luka mukosa bukal tikus wistar dengan konsentrasi terbaik adalah $100 \%$.

Perlu dilakukan penelitian lebih lanjut tentang efektivitas ekstrak haruan terhadap penyembuhan luka dibandingkan dengan obat paten dan penelitian lebih lanjut mengenai uji toksisitas ekstrak ikan haruan.

\section{DAFTAR PUSTAKA}

1. Setyaningsih W, Rachmawati N, Mandala V, Dewi MS, Novita G. Reepitelisasi, kepadatan kolagen pada proses penyembuhan luka gingiva labial tikus sparague dawley setelah pemberian topikal ekstrak buah adas (Foeniculum vulgare Mill.) 50\% [Tesis] Yogyakarta: Fakultas Kedokteran Gigi Universitas Gadjah Mada; 2006

2. Soemardini, Permaningtyas K, Chandra D. Pengaruh pemberian ekstrak ikan gabus (Channa striata) terhadap kadar nitric oxide pada tikus Rattus norvegicus jantan strain Wistar model diabetes melitus. Malang: Fakultas Kedokteran Universitas Brawijaya; 2011. p. 1-3

3. Restiana, Taslim N, Bukhari A. Pengaruh pemberian ekstrak ikan gabus terhadap kadar albumin dan status gizi penderita HIV/AIDS yang mendapatkan terapi ARV. Makassar: Fakultas Kedokteran Universitas Hasanuddin; 2013.p.1-4

4. Santoso AH. Uji potensi ekstrak ikan haruan (Channa striata) sebagai hepatoprotector pada tikus yang diinduksi parasetamol [Tesis]. Bogor: Institut Pertanian Bogor; 2009

5. Adnyana I, Sigit J, Nurlina. Effect of administration of cork fish (Channa striata) concentrate to the blood's profile of balb/c mouse thrombocytopenia model. Jurnal Medika Planta 2012; 2(1): 1-3

6. Yuniarti D, Sulistiyati T, Suprayitno E. Pengaruh suhu pengeringan vakum terhadap kualitas serbuk albumin ikan gabus (Ophiocephalus striatus). THPi Student J 2013; 1(1): 1-2

7. Ama F, Arifin A, Legowo D. Studi pengaruh stimulasi elektrik (ES) pada proses percepatan penyembuhan luka kulit marmut (Cavia cobaya) [Tesis]. Surabaya: Jurusan Teknik Elektro Institut Teknologi Surabaya; 2011

8. Masir O, Manjas M, Putra A, Agus S. Pengaruh cairan cultur filtrate fibroblast (CFF) terhadap penyembuhan luka pada Rattus norvegicus galur Wistar. J Kesehatan Andalas 2012; 1(3): 1-2

9. Sugiaman VK. Peningkatan penyembuhan luka di mukosa oral melalui pemberian Aloe vera (Linn.) secara topikal. J Kedokteran Maranatha 2011; 11:1

10. Prasetyo BF, Wientarsih I, Pontjo B. Aktivitas sediaan salep ekstrak batang pohon pisang ambon (Musa paradisiaca var.sapientum) dalam proses penyembuhan luka pada mencit (Mus musculus albinus). Majalah Obat Tradisional 2010; 15(3): 121-37

11. Pematasari N, Pasaribu R, Razaq A. Efektivitas ekstrak ginseng Asia (Panax ginseng) dalam meningkatkan jumlah pembuluh darah pada soket mandibula pasca pencabutan gigi Rattus norvegicus. Malang: Fakultas Kedokteran Universitas Brawijaya; 2012: 1-2

12. Borkow G. Copper's role in wound healing. Property of Cupron Inc.; 2004.p.1-12

13. Burns JL, Mancoll JS, Phillips LG. Impairments to wound healing. Clin Plastic Surg 2003; 30(1): 47-56

14. Soepriadi I. Regenerasi dan penyembuhan. Jakarta: Sagung Seto; 2013. hal.7-11

15. Kumar V, Cotran LS, Robbins SL. Buku ajar patologi. Alih bahasa: Prasetyo A, Pendit BU, Priliono T. Jakarta: EGC; 2007. hal. 80-2

16. Sandra F, Frisca. Angiogenesis: patofisiologi dan aplikasi klinis. J Kedokteran Maranatha 2009; 8(2): 174-87

17. Sura GM. Efektivitas ekstrak ikan haruan (Channa striata) $100 \%$ pada proses penyembuhan luka kulit punggung mencit (Mus musculus) secara gambaran histopatologi [Skripsi]. Program Studi Kedokteran Gigi Fakultas Kedokteran Universitas Lambung Mangkurat Banjarmasin; 2014. hal. 21

18. Jannata RH, Gunadi A, Ermawati E. Daya antibakteri ekstrak kulit apel manalagi (Malus sylvestris mill.) terhadap pertumbuhan Streptococcus mutans. e-Jurnal Pustaka Kesehatan 2014; 2(1), 26-7 